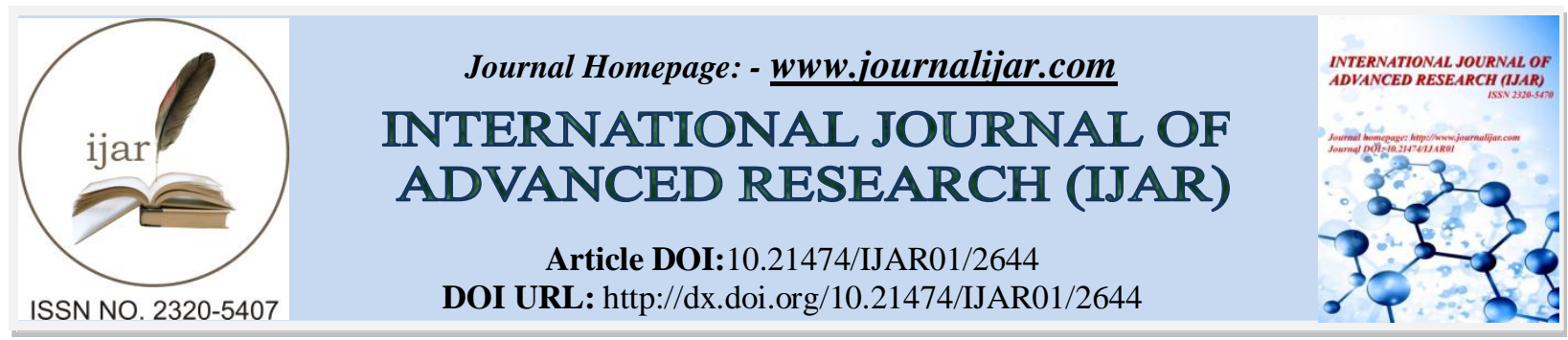

RESEARCH ARTICLE

\title{
NEW DEVELOPMENTS IN ANTICANCER ACTIVITIES OF IMIDAZOLE AND ITS DERIVATIVES.
}

Rambhau P. Gore.

University Institute of Chemical Technology, North Maharashtra University, Jalgaon-425001.

\section{Manuscript Info}

Manuscript History

Received: 30 October 2016

Final Accepted: 29 November 2016

Published: December 2016

\section{Key words:-}

Imidazole, Imidazole derivatives, biological activity, anticancer agent, multi-drug resistance.

\section{Abstract}

The heterocyclic compounds are well known for their diverse biological and clinical applications. The pharmacological importance of imidazole has been well established. It is constituents of important biomolecules such as histidine, biotin and alkaloids. Imidazole drugs are well-tolerated and are potentially active on number of targets, because of its polar and ionizable nature it will increase the solubility and bioavailability of the lead molecules. Moreover, nucleotides and imidazole derivatives are structural isosters so their interaction is responsible for delivering numerous biological activities and functions in living system. In view of these, the present review focus on the anticancer activities of imidazole nucleus.

Copy Right, IJAR, 2016,. All rights reserved.

\section{Introduction:-}

The worldwide threat of cancer is increasing day by day in low-income and middle-income countries. A report on cancer estimated that, the cases of cancer per year worldwide are greater than 14 million, and projected to increase to nearly 22 million by 2030[1].Cancer is a devastating disease, characterized by uncontrolled growth of cells which results to invade surrounding tissue and in turn, ultimate destruction. The present day anti-cancer drugs show limited efficacy, single targeted with severe side effects $[2,3,4]$. Also years of misuse results into chemo-resistance and multi-drug resistance in tumor cell, which is a major problem in cancer chemotherapy [5].

Imidazole display broad spectrum of biological activities acting on number of biological targets, such as antibacterial, antitubercular, antifungal, local and systemic fungal infections [6,7,8], analgesic [9], antiviral, antidiabetics [10,11], anthelmintic, anti-inflammatory, anticonvulsant [12], antioxidant,antihemolytic, [13,14], antiHIV [15], and anticancer [16,17,18]. The high therapeutic properties of the imidazole making it as a common structural motif in pharmacological important molecules. Several classes of drugs are imidazole based commonly called as azomycin such as cimetidine, metronidazole, clotrimazole [19]. The 2-arylamino imidazole reported as selective against $\alpha$-adrenoceptors [20]. 
<smiles>Clc1ccccc1C(c1ccccc1)(c1ccccc1)n1ccnc1</smiles>

1<smiles>Cc1ncc([N+](=O)[O-])n1CCO</smiles>

2

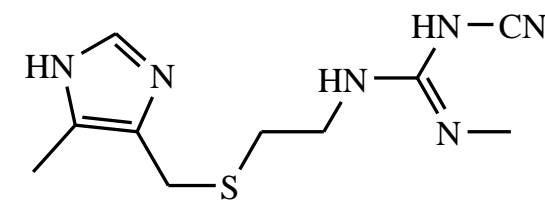

3

Clotrimazole

Metronidazole

Cimetidine

The imidazole derivatives, Dacarbazine(DTIC),Temozolomide(TMZ) are active against lymphoma and malignant melanoma [21]. Thus, the incorporationof imidazole nucleus is an important strategy in the drug discovery.<smiles>CN(C)/N=N/c1[nH]cnc1C(N)=O</smiles>

4

Dacarbazine<smiles>Cn1nnc2c(C(N)=O)ncn2c1=O</smiles>

5

Temozolomide<smiles>NC(=O)c1csc([C@@H]2O[C@H](CO)[C@@H](O)[C@H]2O)n1</smiles>

6

\section{Results and Discussion:-}

The new C-nucleoside analogue of Tiazofurin (6), synthesized by Franchetti et al., reported to have good anti-cancer activity against leukemia K562 cells [22].

The imidazole alkaloids, naamidine A, (7)isolated form sponge Leucetta, exhibits good anticancer activities by regulation of ERK1 and ERK2,this in turn, stimulates p21 level andarrests cell cycle at G1 phase [23].

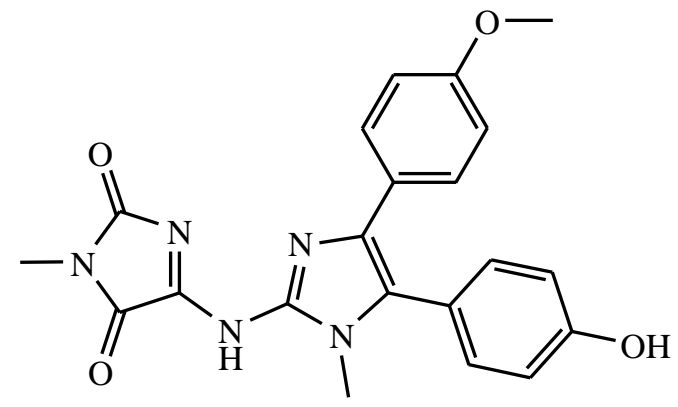

7<smiles>COc1cc(-c2cn(-c3ccccc3)c(=O)[nH]2)cc(OC)c1OC</smiles>

8

Congiu et al., reported new imidazole derivative $(8), 1,4$-diarylimidazol-2(3H)-one with potent anti-tumor activity against T-lymphoid cells. The author observed that the compound having 3,4,5-trimethoxyphenyl ring either at $\mathrm{N}-1$ or C-4 position shows cytotoxicity against leukemia cell lines [24].

Hadfield et. al.,also observed the same 3,4,5-trimethoxyphenyl ring was essential to show anti-tumor activity, which inhibits tubulin polymerization [25]. The similar trimethoxy substituted xanthenoimidazole derivatives have synthesized by Kostakis I. K. et. al., which shows inhibitory activity against breast cancer cell lines [26].Elahian F. et. al., synthesized and studied the anticancer activity of 2,4,5-triaryl imidazole derivatives by MTT assay against T47D and MDA-MB231 cell lines having significant $\mathrm{IC}_{50}$ value in cell culture assay [27]. 
A series of new 2,4,5-trisubstituted and 1,2,4,5-tetrasubstituted imidazoles screened by Malhotra S. et al., against the National Cancer Institute's 60 human cancer cell lines, in which compound (9) found as potent against A549 human lung cancer cell line with $\mathrm{IC}_{50}$ value $9 \mu \mathrm{M}$. The reason for cell proliferation inhibition was found related to loss of morphology, inhibition of cell migration and cell cycle arrest through senescence [28].

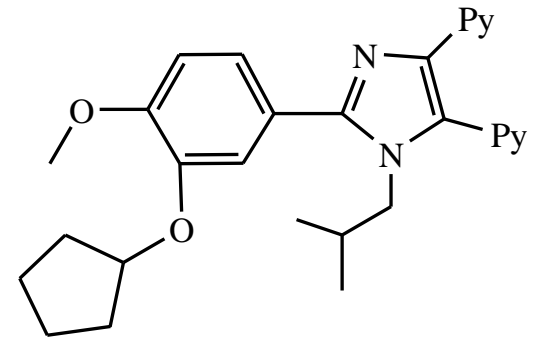

9<smiles>[R]c1nc(-c2ccccc2)c(-c2ccccc2)[nH]1</smiles>

10

Chakrabhavi D. M. et. al., reported trisubstituted imidazole derivatives (10), which induces apoptosis inHuman breast cancer cells by suppressing overactivation of PI3K/Akt/mTOR signaling pathway in breast cancer cells [29].

Ozkay et. al.,have synthesizedtrisubstituted Imidazoleacetamide derivatives(11), indicated significant anticancer activity against colon carcinoma cell line with DNA fragmentation of the HT-29 cells [30].

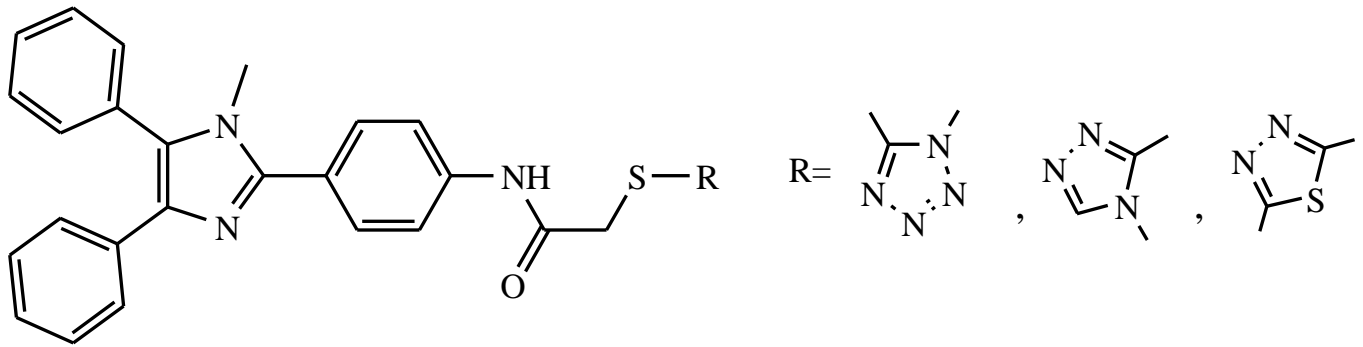

11

A novel series of imidazole derivatives $(\mathbf{1 2}, \mathbf{1 3})$,synthesized and evaluated for anticancer activity by Bendgude R. D. and Kondewar M. S., reported few compounds exhibited significant inhibitory activities against MDA MB 4355 Human breast cancer cells with MTT assay at $20 \mu \mathrm{g} / \mathrm{ml}$ compared with the standard drug 5 -fluorouracil $(10 \mu \mathrm{g} / \mathrm{ml})$ [31].

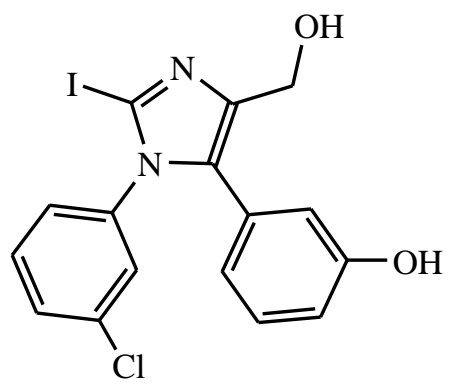

12<smiles>O=[N+]([O-])c1ccccc1-n1c(I)nc(CO)c1-c1ccc(Br)cc1</smiles>

13

Finley et. al., reported small molecule CDK cell cycle inhibitors (14), which play important role in regulation of cell cycle and known to overexpress in most human cancers [32].<smiles>Cc1ncc(-c2ccnc(Nc3ccc(N4CCNCC4)cc3)n2)n1C(C)C</smiles> 
Gursoy T. N. et. al., have synthesized new series of imidazole fused thiadiazolecarbohydrazide derivatives(15,16). These compounds have shown in vitro anticancer activities against lung, breast and CNS cell lines. The hydroxyl and nitro substituted derivatives were found highly active against ovarian and breast cancer cell lines compared with standard drugs chlorambucil, 5-fluorouracil and melfalan [33].<smiles>Cc1nn2c(C(=O)N=Nc3ccccc3O)c(C)nc2s1</smiles>

15<smiles>Cc1nn2c(C(=O)N=Nc3ccccc3[N+](=O)[O-])c(C)nc2s1</smiles>

16

Soraya S. and Soraya S. S. reported the computational studies on effects of 1-(4-chlorobenzylidineamino)-4-phenyl1H-imidazol-2-amine (17), as an anticancer drug on DNA. The authors studied the bending of drug with nucleotides, Adenine, Cytosine, Guanine and Thymine and reported the highest amount of interaction in between the drug and Guanine [34].<smiles>Nc1nc(-c2ccccc2)cn1/N=C/c1ccc(Cl)cc1</smiles>

17<smiles>[R]c1ccccc1-c1c[nH]c(NC(=O)CS(=O)(=O)NS(=O)(=O)CC(=O)Nc2nc(-c3ccccc3[R])c[nH]2)n1</smiles>

$\mathrm{R}, \mathrm{a}=\mathrm{Ph}, \mathrm{b}=4 \mathrm{Me}, \mathrm{c}=4 \mathrm{cl}$

18

C. Premakumariet. al., have reported anticancer activities of bisimidazolesulfonyl derivatives (18)against NCIH11299, HCT-166 p53 and PC-3 cell by EZ-cytox cell viability assay kit. The compounds are found potent on lung, colon, and prostate cancer cell lines [35].Fahimah M. I. et. al., Synthesized and tested $\mathrm{Cu}$ complexes of triphenylimidazoles for anticancer activities. The complex showed $\mathrm{IC}_{50}$ value of $8.7 \mu \mathrm{M}$ for liver carcinoma (HEPG2) against standard drug doxorubicin $(4.73 \mu \mathrm{M})[36]$.

Sharma G. K. et al., have synthesized and screened some imidazole acetamides (19),for inhibition study against Dalton's Lymphoma Ascites (DLA) and Ehrlich Ascites Carcinoma (ECA) cell lines showing significant cytotoxic activity [37].<smiles>CC(=O)Nc1ccc(-c2csc(-n3c(C)nc(C)c3C)n2)cc1</smiles>

19

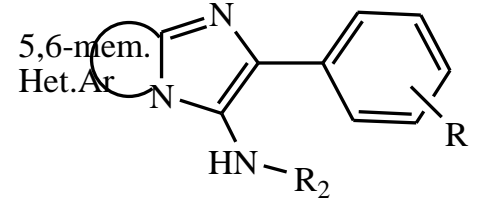

20

Baviskar A. T. et. al.,have reported bicyclic $\mathrm{N}$-fused aminoimidazoles (20), as an important target in anticancer drug discovery, topoisomerase inhibitor. These compounds showed anticancer activities in kidney and breast cancer cell lines with inhibition of cell migration [38]. Fei Y., et. al., have reported polyamide of pyrrole-imidazole with antitumor activity in prostate tumor. The polyamide binds with the minor groove of DNA with high affinity and activates p53 signaling in LNCaP prostate cancer cells without targeting DNA [39].

Lan-Xiang Liu et al., reported anticancer activities of hybrid compounds of salts of carbazole and imidazole. The imidazolium salt (21),known to exhibits anticancer activities by arresting cell cycle progression and apoptosis $[40,41]$. 

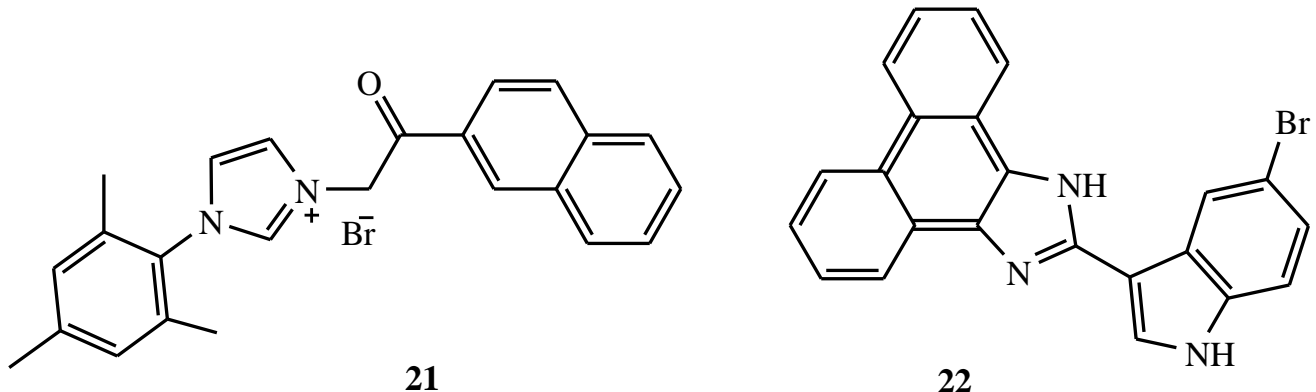

Jubo L. et al., have form formulation of aryl-imidazole(22) with liposomes. The lipophilic ML220 imidazole derivative,2-(5-bromo-1H-indol-3-yl)-1H-phenantro[9,10-d]imidazole, entrapped within the aqueous interior of the liposomes by amphiphilic nature of imidazole moiety. This type of formulations is FDA approved and were used for doxorubicin and daunorubicin [42].

\section{Conclusion:-}

The present review gives brief insight of imidazole derivatives anticancer activities. Imidazole and its derivatives are important heterocyclic compounds in medicinal chemistry. The nature provided derivatives, the derivatives with aromatic molecules, complexes with metal ions, salts, polyamides, liposome formulations, hybrid molecules, by these number of ways imidazole moiety is incorporated to harness its biological activities. The illustrations of some of marketed drugs and promising imidazole derivatives which have been synthesized and tested against number of human cancer cell line will motivates the researchers for future designing of target molecule and study of SAR.

\section{Acknowledgement:-}

The author grateful to Director, UICT, NMU, Jalgaon for providing infrastructural facility and TEQIP-II for providing financial support for the research work.

\section{References:-}

1. Bray F., Jemal A., Torre L. A., Forman D., Vineis P. (2015). Long-term realism and cost-effectiveness: primary prevention in combatting cancer and associated inequalities worldwide. J Nat Cancer Inst. 107: djv273.

2. Shanmugam M.K., Rane G., Kanchi M.M., Frank A., Chinnathambi A., Zayed M.E., Alharbi A.S., Tan B.K.H., Premkumar A., Sethi G. (2015). The multifaceted role of curcumin in cancer prevention and treatment, Molecules 20: 2728-2769. doi: 10.3390/molecules20022728.

3. Abdel Aziz M.T., El-Asmar M.F., Rezq A.M., Fouad H.H., Ahmed H.H., Hassouna A.A., Taha F.M., Hafez H.F. (2012). Novel anticancer curcumin derivative with conserved functional groups. Cancer Ther\& Res. doi: 10.7243/2049-7962-1-10.

4. Ahsan M.J., Khalilullah H., Yasmin S., Jadhav S.S., Govindasamy, J. (2013). Synthesis, characterization and in vitro anticancer activity of curcumin analogues bearing pyrazole/pyrimidine ring targeting EGFR tyrosine kinase. Bio Med Res Int, article ID 239354, pages 14.

5. Balasubramanian N., Sharma D., Kumar P. (2011). Biological importance of imidazole nucleus in the new millennium. Med Chem Res, 20: 1119-1140.

6. Boiani M., Gonzalez M. (2005). Imidazole and benzimidazole derivatives as chemotherapeutic agents. Mini Review Med Chem, 5:409-424.

7. Wright S, W., Harris R. R., Collins R. J., Corbett R. L., Green A. M., Wadman E. A., Batt D. G. (1992). Novel 1-(pyridylphenyl)-1-phenyl-2-imidazolylethanols with topical anti-inflammatory activity. J Med Chem, 35: 3148-3155.

8. Delia H. R., Victor E. T. H., Oscar G-B., Ma Elizabeth M. L., Esmeralde S. P. (2014). Synthesis of imidazole derivatives and their biological activities. J ChemBiochem, 2(2): 45-83.

9. Shalini K., Kumar N., Sharma P. K. (2011). Synthesis of N-((2-substituted phenyl)-4,5-diphenyl-1H-imidazol1-yl) methylphenyl substituted amine derivatives, spectral characterization and their pharmacological evaluation. Biointerface Res, 1: 184-190.

10. H. M. Alkahtani, A. Y. Abbas, S. Wang. (2012). Synthesis and biological evaluation of benzo[d] imidazole derivatives as potent anti-cancer agents.Bioorg. Med. Chem. Lett. 22(3): 1317-1321.

11. Gupta P., Gupta J. K. (2015). Synthesis and bioactive imidazoles: A review. ChemSci J. 6(2): 1-12. 
12. Pinza M., Farina Z., Cerri A., Pfeiffer U., Riccaboni M. T., Banfi S., Biagetti R., Pozzi M., Magnani M., Dorigotti L. (1993). Synthesis and pharmacological activity of a series of dihydro-1H-pyrrolo[1,2-a] imidazole2,5-(3H,6H)-diones, a novel class of potent cognition enhancer. J Med Chem, 36: 4214-4220.

13. Soujanya Y., Sastry G. N. (2007). Theoretical elucidation of the antioxidant mechanism of 1,3-dihydro-1methyl-2H-imidazole-2-selenol (MSeI). Tetrahedron Lett, 48(12):2109-2112.

14. Abdel-Wahab B. F., Awad G. E. A., Badria F. A. (2011). Synthesis, antimicrobial, antioxidant, anti-hemolytic and cytotoxic evaluation of new imidazole-based heterocycles. Eur J Med Chem, 46: 1505-1511.

15. Zhan P., Liu X., Zhu J., Fang Z., Li Z., Pannecouque C., Clercq E. D. (2009). Synthesis and biological evaluation of imidazole thioacetanilides as novel non-nucleoside HIV-1 reverse transcriptase inhibitors. Bioorg Med Chem, 17(16): 5775-5781.

16. Sharma G. K., Sharma N. K., Pathak D. (2013). Microwave irradiated synthesis of some substituted imidazole derivatives as potential antibacterial and anticancer agents. Ind J Chem, 52B: 266-272.

17. Xiao-Dong Y., Wei-Chao W., Xiao-Yan D., Yan L., Li-Juan Y., Liang L., Hong-Bin Z. (2012). Design, synthesis and cytotoxic activities of novel hybrid compounds between 2-phenylbenzofuran and imidazole. Bioorg Med Chem Lett., 22: 2726-2729.

18. Junghun L., Hwan K., Hana Y., Jae Y. C., Chang-Hyun O., Kyung H. Y., Taebo S., Jung-Mi H. (2010). Discovery and initial SAR of pyrimidin-4-yl-1H-imidazole derivatives with antiproliferative activity against melanoma cell lines. Bioorg Med Chem Lett., 20: 1573-1577.

19. Desai N. C., Maheta A. S., Rajpara K. M., Joshi V. V., Vaghani H. V., Satodiya H. M. (2014). Green synthesis of novel quinolone based imidazole derivatives and evaluation of their antimicrobial activity. J Saudi Chem Soc., 18: 963-971.

20. Munk S. A., Harcourt D. A., Arasasingham P. N., Burke J. A., Kharlamb A.B., Manlapaz C. A., Padillo E. U., Roberts D., Runde E., Williams L., Wheeler L A., Garst M. E. (1997). Synthesis and evaluation of 2(arylamino) imidazole as a 2-adrenergic agonists. J Med Chem, 40: 18-23.

21. Yaseen A. Al-S., Haitham H. Al-S., Houssain A. S. A., Kifah S. M. S., Mohammad S. M., Najim A. Al-M., Ihsan H. J. (2007). Synthesis, characterization antitumor and anti-HIV activities of new coumarin derivatives. Z. Naturforsch, 63b: 83-89.

22. Franchetti P., Marchetti L. S., Cappaellaci J. A., Yalowitz H. N., Jayaram B. M., Glodstein M., Grafantini A. (2001). New C-nucleoside analogue of tiazofurin: Synthesis and biological evaluation of 2- $\beta$ ribofuranosylimidazole-4-carboxamide (imidazofurin). Bioorg Med Chem, Lett., 11: 67-69.

23. Lidia D L. (2006). Naturally occurring and synthetic imidazoles: Their chemistry and their biological activities. Curr Med Chem, 13: 1-23.

24. Congiu C., Cocco M. T., Onnis V. (2008). Design, synthesis and in vitro antitumor activity of new 1,4diarylimidazole-2-ones and their 2-thione analogues. Bioorg Med Chem Lett., 18: 989-993.

25. Hadfield J. A., Ducki S., Hirst N., McGown A. T. (2003). Tubulin and microtubules as targets for anticancer drugs. Prog Cell Cycle Res, 5: 309-325.

26. Kostakis I. K., Pouli N., Marakos P., Kousidou O. C., Roussidis A., Tzanakakisc G. N., Karamanos N. K. (2008). Design, synthesis and cell growth inhibitory activity of a series of novel aminosubstitutedxantheno[1,2d] imidazole in breast cancer cells. Bioorg Med Chem, 16: 3445-3455.

27. Elahian F., Akbari M., Ghasemi M., Behtooee N., Taheri M., Amini M. (2014). Synthesis and anticancer activity of 2,4,5-triarylimidazole derivatives. Lett., in Drug Design \& Discovery, 11 (7): 840-843.

28. Sharma G.V.M., Ramesh A., Singh A., Srikanth G., Jayaram V., Duscharla D., Jun J.H., Ummanni R., Malhotra S.V. (2014). Imidazole derivatives show anticancer potential by inducing apoptosis and cellular senescence. Med ChemCommun, 5: 1751-1760.

29. Chakrabhavi D. M., Srinivasa V., Rangappa S., Mervin L., Surender M., Paricharak S., Sefer B., Feng L., Shanmugam M. K. et al. (2016). Trisubstituted-Imidazoles induce apoptosis in human breast cancer cell by targeting the oncogenic PI3K/ Akt/ mTOR signaling pathway. PLOS one. doi: 10.1371/journal.pone.0153155.

30. Ozkay Y., Isikdag I., Incesu Z., Akalin G. (2010). Synthesis of 2-Substituted-N-[4-(1-methyl-4,5-diphenyl-1Himidazol-2-yl) phenylacetamide derivatives and evaluation of their anticancer activity. Eur J Med Chem, 45: 3320-3328.

31. Bendgude R. D., Kondewar M. S. (2016). Anticancer studies of novel 2-iodo-4-hydroxymethyl-1,5diphenylsubstituted-1H-imidazole derivatives. Eur J Biomed Pharmaceutical Sci., 3(11): 204-207.

32. Finley M. R. V., Acton D. G., Andrew D. M., Barker A. J., Dennis M., Fisher E., Graham M. A., Green C. P., et. al. (2008). Imidazole piperazine: SAR and development of a potent class of cyclin-dependent kinase inhibitors with a novel binding mode. Bioorg Med Chem Lett., 18: 4442-4446. 
33. Gursoy T. N. (2003). Synthesis and anticancer evaluation of some new hydrazine derivatives of 2,6dimethylimidazo[2,1-b][1.,3,4]thiadiazole-5-carbohydrazide. Eur J Med Chem, 38: 781-786.

34. Soroor S., Seyed S. S. (2012). Affectivity of the imidazole anticancer drug on the diagnosis of the cancers by using quantam chemical methods. $4^{\text {th }}$ International conference on Bioinformatics and Biomedical Technology. IPCBEE 29: 187-190.

35. Premakumari C., Akkarapalli M., Adivireddy P., Venkatpuram P., Sea J. P., Tack-Joong K., Guda D. R. (2014). Synthesis, antimicrobial and anticancer activities of amidosulfonamido methane linked bis heterocycles. Arabian J Chem, 7: 385-395.

36. Fahimah M., Iin C., Ayu W. (2016). Synthesis, spectral, anticancer studies on $\mathrm{Cu}$ (II) complex of 2,4,5triphenyl-1H-imidazole. JurnalPenelitiandanPengembangan 2(2): 91-96.

37. Sharma G. K., Suresh K., Pathak D. (2010). Synthesis, antibacterial and anticancer activities of some novel imidazoles. Der Pharmacia Lett, 2(2); 223-230.

38. Baviskar A. T., Madaan C., Preet R., Mohapatra P., Jain V., Agarwal A., Guchhait S., Kundu C. N., Banerjee U. C., Bharatam P. V. (2011). N-fused imidazoles as novel anticancer agents that inhibits catalytic activity of Topoisomerase II $\alpha$ and induce apoptosis in G1/S phase. J Med Chem, 54: 5013-5030.

39. Fei Y., Nicholas G. N., Benjamin C. L., Georgi K. M., Jonathan W. S., Peter B. D. (2013). Antitumor activity of a pyrrole-imidazole polyamide. PNAS 110(5): 1863-1868.

40. Lan-Xiang L., Xue-Quan W., Bei Z., Li-Juan Y., Yan L., Hong-Bin Z., Xiao-Dong Y. (2015). Synthesis and antitumor activity of novel N-substituted carbazole imidazolium salt derivatives. Sci Reports 5: 13101

41. Zeng, X. H., Yang, X. D., Zhang, Y. L., Qing, C. \& Zhang, H. B. (2010). Synthesis and antitumor activity of 1mesityl-3-(2-naphthoylmethano)-1H-imidazolium bromide.Bioorg. Med. Chem. Lett. 20:1844-1847.

42. Jubo L., Helen L., Mario H., Aiping Y., Christine A. (2006). Liposome formulation of a novel hydrophobic aryl-imidazole compounds for anti-cancer therapy. Can ChemotherPharmacol, 58: 306-318. 